\title{
1. Introduction: Republican moments, Machiavelli and digital communications
}

\begin{abstract}
Any serious discussion of freedom of expression and news gathering/ dissemination - one that seeks not to have become obsolescent in as short a time frame as ten or 15 years in the future - needs to consider the available evidence about emerging trends in which news content is generated and disseminated. In September 2012, the Pew Research Center - a Washington DC-based, independent public opinion research centre - published data about the consumption of news stories by US citizens. ${ }^{1}$ Not only did the research confirm a previously detected decline in print newspaper sales, ${ }^{2}$ it also revealed that television news had begun to lose a younger generation of news consumers. This group (comprising adults under the age of 30) is turning increasingly to online/mobile sources of news information. Across all age groups, the percentage of US citizens that acquired their news from a social networking site more than doubled from 9 per cent in 2010 to 19 per cent in 2012. For the under-30s, social networking sites provided the preferred source of news for 33 per cent of this group. By comparison, television news broadcasts were viewed by 34 per cent of under-30s while just 13 per cent obtained their news from a newspaper (in print and digital formats). More recent data from Pew confirms that among 'millennials' (persons born between
\end{abstract}

1 Pew Research Center, 'In changing news landscape, even television is vulnerable' (September 2012) at http://www.people-press.org/subjects/newsconsumption/.

2 The declining viability of newspapers in the US is evidenced by a pattern of regular change of ownership as successive proprietors try and fail to arrest falling circulation levels that in turn generate less and less advertising revenue, see Pew Research Center, 'The declining value of US newspapers' (May 2015) at http://www.people-press.org/2012/09/27/in-changing-news-land scape-even-television-is-vulnerable/. 
1981 and 1996) Facebook is the most visited source of political information for 61 per cent of this group of US citizens. ${ }^{3} C N N$ is next, having 44 per cent of millennials view the cable news programme for political content. Conversely, among the baby-boomer generation (persons born between 1946 and 1964) 60 per cent of this group continue to go to local news channels for news about politics and government. The Pew Center's figures are indicative of a broader trend outside the US. In the UK, sales of print newspapers are also in sharp decline. Currently, free newspapers (such as Metro and the London Evening Standard) have begun to eat into the share of the market hitherto occupied by paid-for titles. In the period from 2008-14, national newspaper print circulations saw a steady decline. The Sun (from $3.2 \mathrm{~m}$ to $2.02 \mathrm{~m}$ ), the Daily Mail $(2.2 \mathrm{~m}$ to $1.7 \mathrm{~m}$ ), the Daily Mirror (1.4m to $1 \mathrm{~m}){ }^{4}$ Sales of The Daily Telegraph fell from 850,000 to 505,000, while The Guardian saw its sales fall from 350,000 to $180,000 .^{5}$ By contrast urban freesheets such as the Metro and the Evening Standard claim respectively $3.2 \mathrm{~m}^{6}$ and 900,000 readers of hard copy newspaper editions. ${ }^{7}$

It is not clear however that even free printed newspapers will survive in the medium term in a rapidly evolving and highly competitive market. Advertisers who currently finance the freesheets can reach a new generation of potential customers via social networking sites and are likely to take their marketing activities increasingly online forcing publishers to compete for online readers. If US trends are anything to go by, the hard copy version of the Metro and its like will soon disappear as new generations of news consumers opt in increasing numbers to access content from their mobile devices. By September 2014, more than 21 per cent of persons who read newspapers in the UK did so exclusively via their mobile phones. ${ }^{8}$

3 Pew Research Center, 'Facebook top source for political news among millennials' (June 2015) at http://www.journalism.org/2015/06/01/millennialspolitical-news/.

4 R Greenslade, 'ABC figures show papers' efforts to stem circulation decline' The Guardian, October 10, 2014.

5 See for more recent data confirming this trend http://www.the guardian.com/media/2015/apr/10/national-daily-newspapers-lose-more-than-halfa-million-readers-in-past-year (April 2015).

6 http://metro.co.uk/2013/10/15/metros-audience-4164994/ (figure quoted is for 2013).

7 http://www.newsworks.org.uk/London-Evening-Standard (figures published in June 2015).

8 http://www.themediabriefing.com/article/one-fifth-of-uk-newspapers-reader ship-is-exclusively-on-mobile (September 2014). 
Aside from the issue of passive forms of news consumption, the explosion in social media platforms and other forms of digital communication now allows all of us (whether professional journalists or not) to communicate information and opinion (and falsehoods!). This in turn creates the potential for each of us to cause damage to private interests (such as the reputational/privacy/intellectual property interests of others) and more obviously public concerns such as the administration of justice by posting prejudicial material online or publishing data relating to national security. Indeed, the chances of such material appearing on electronic media would seem to be all the greater because of the absence of editorial checking processes usually employed in those sections of the traditional print and broadcast news media generally considered 'responsible' and, in the case of substantial number of tweeter/bloggers etc., a relative lack of legal knowledge/access to legal advice about the reach of defamation/contempt/privacy etc., laws. After all, as Levi notes, bloggers view themselves as journalists but will often lack the levels of professional training associated with the mainstream press and broadcasting sectors. ${ }^{9}$ At the same time, mainstream traditional press and broadcasting outlets invite 'community participation' in news production. ${ }^{10}$ Mobile phone camera footage shot by an individual at the location of a developing news story frequently finds its way onto television screens and online journalism forums. Journalists are increasingly reliant upon Twitter feeds from politicians and others to source and obtain comment upon news stories. The technique of 'crowdsourcing' is now openly deployed by serious media outlets such as The Guardian to allow its online readership to collaborate in identifying emerging news stories and providing content for these (as well as supplementing existing news lines and investigations). ${ }^{11}$

The idea of a digitised public sphere which has transformed the average citizen's hitherto largely passive experience of political debate led by elite opinion formers into something much more vibrant and more participative has been around for a while. Those who have made this democratisation argument have stressed the empowering feature of what

\footnotetext{
9 L Levi, 'Social media and the press' (2012) 90 NCL Rev 1531, 1533.

10 Ibid.

11 Some local newspapers in the UK are turning to user-generated content as a means of increasing web traffic flows to newspapers' websites, see I Burrell, 'The dizzying decline of Britain's local newspapers: do you want the bad news, or the good news?' The Independent, August 31, 2014.
} 
Volokh famously described as 'cheap speech'. ${ }^{12}$ 'The new technologies ... will, I believe, both democratize the information marketplace - make it more accessible to comparatively poor speakers as well as the rich ones - and diversify it. ${ }^{13}$

Tom Brokaw the respected NBC anchorman referred to bloggers as representing the 'democratization of the news'. ${ }^{14}$ His successor Brian Williams noted with some bitterness the competitor element introduced by bloggers, observing that he was now 'up against a guy called Vinny in an efficiency apartment in the Bronx who hasn't left the efficiency apartment in two years'. ${ }^{15}$

In 1997, Justice Stevens in the US Supreme Court ruling Reno v ACLU spoke of the facility offered by online 'chatrooms' that would enable anyone to become a 'town crier with a voice that resonates further than it would from a soap box'. ${ }^{16}$ On this side of the Atlantic the Council of Europe's Committee of Ministers has more recently affirmed that:

Citizens' communication and interaction in online environments and their participation in activities that involve matters of public interest can bring positive, real-life, social change. When freedom of expression and the right to receive and impart information and freedom of assembly are not upheld

12 See for example the remarks of Joe Trippi in 2004. Trippi was campaign manager for Howard Dean's bid to secure the US Democrat Party's nomination for President when he stated: 'The Internet is the most democratising innovation we have ever seen, more so even than the printing press. Nothing will ever be the same' cited in M Hindman, The Myth of Digital Democracy (Princeton University Press, New Jersey, 2009).

13 E Volokh, 'Cheap speech and what it will do' (1995) 104 Yale L J 1805, 1833 available electronically at http://www2.law.ucla.edu/volokh/cheap.pdf. The quote continues: 'Of course the power to make one's speech globally available isn't the power to make it globally heard' - a point which is returned to at various points below. See further P Schwartz, 'Privacy and democracy in cyberspace' (1999) 52 Vand L Rev 1609 arguing over a decade ago that the internet had the capacity to become central to political dialogue among citizens.

14 Brokaw is quoted in $\mathrm{J}$ Guthrie 'Fellow anchors defend rather on forged papers' San Francisco Chronicle, October 3, 2004.

15 Cited by R Fox and J Ramos, IPolitics, Citizens, Elections and Governing the New Media Era (CUP, Cambridge, 2012), p. 10. See in similar vein CNN Executive Jonathan Klein's remarks contrasting the system of checks that are the hallmark of serious investigative journalism and the absence of similar controls over the citizen blogger. The internet, Klein argued, has given 'too much power to a guy sitting in his living room in his pyjamas', cited in P Anderson, G Ogola and M Williams (eds), The Future of Quality News Journalism - A Cross Continental Analysis (Routledge, London, 2013), p. 189.

16 Reno v ACLU (1997) 521 US 844, 862. 
online, their protection offline is likely to be undermined and democracy and the rule of law can also be compromised. ${ }^{17}$

The development of social media platforms is clearly a pivotal moment in the movement away from elite-driven narratives to citizen-centred exchanges about politics. ${ }^{18}$ Some US commentators have recently gone so far as to claim that social media sites in particular make possible an increased frequency of 'republican moments', ${ }^{19}$ by which is meant those occasions when (i) ordinary citizens engage much more fully in political debates than is usual, and (ii) this engagement is successful in shaping the eventual policy outcome of the aforementioned debate as the rival positions of more organised and established special interest/pressure groups are overcome. ${ }^{20}$ Interest in a modernised version of republicanism theory can however be traced to an earlier pre-social media, pre-internet era. The late 1980s witnessed a revival largely among (but not confined to) US academics in civic republicanism as liberalism came increasingly to be seen as endorsing apathy in matters of self-government and failing to inculcate the sorts of values needed for healthy communities. This background is returned to shortly.

The reasons why republican-based accounts of the constitution continue today to command interest in the era of citizen journalism are worthy of closer attention. Some argue that Facebook, Twitter and other social media sites create new opportunities for deliberation in conditions of approximate political equality among citizens. ${ }^{21}$ Others have cautioned that the ability of users to personalise the information to which they are exposed coupled with the human psychological trait that seeks out material which endorses rather than is critical of the user's existing beliefs has a detrimental impact on the range of viewpoints to which users are exposed with the consequence that the possibility for a richer,

17 Declaration by the Committee of Ministers on the protection of freedom of expression and information and freedom of assembly and association with regard to Internet domain names and name strings (Adopted by the Committee of Ministers on 21 September 2011) available electronically at https:// wcd.coe.int/ViewDoc.jsp?id=1835805.

18 For a useful overview, see J Rowbottom, 'Media freedom and political debate in the digital era' (2006) 69 MLR 489.

19 S Tran, 'Cyber-Republicanism' (2013) 55 Wm \& Mary L Rev 383, 399.

20 J Pope, 'Republican moments: The role of direct popular power in the American constitutional order' (1990) 139 U Pa L Rev 287.

21 Arguments that such platforms have also undermined the capacity for informed self-government are discussed below. 
more open dialogue is curtailed. ${ }^{22}$ More negatively still, some predict that the decline of the traditional print media sector will threaten democratic norms in two distinct ways, impacting adversely on both (i) the range of investigative reporting and dissemination of information relevant to the formation of public opinion; and (ii) the frequency of legal challenges to a range of reporting restrictions hitherto brought by newspaper organisations with deeper pockets to challenge reporting restrictions. ${ }^{23}$ On this side of the Atlantic for example, ${ }^{24}$ notable print media sector successes in the courtroom include Sunday Times $v$ UK which resulted in a liberalisation of contempt laws, ${ }^{25}$ Observer and Guardian $v U K$ on the use of permanent injunctions to protect national security where the information in question was no longer confidential, ${ }^{26}$ and Guardian and News Media Ltd and Ors to overturn reporting restrictions relating to persons subject to control orders derived from counter-terrorism laws. ${ }^{27}$ It is to be doubted whether new media entities have either the deep pockets or a principled commitment to fighting freedom of expression causes that characterised the previous era. The absence of one or other bodes ill for formal legal challenges to governmental restrictions.

\section{LIBERAL PLURALIST AND REPUBLICAN CONCEPTIONS OF DEMOCRACY}

Baker reminds us that, prior to any assessment of the value of a free media to a democracy, there has first to be a theory of democracy in place. $^{28}$ Two prominent rival theories that underpin media freedom debates in this regard are: (i) liberal/pluralist; and (ii) republican conceptions. In this section of materials the key features of each are set out. Each conception attaches importance to the equality of individuals to participate in societal affairs and respects each citizen as a moral agent.

\footnotetext{
22 C Sunstein, Republic.com 2.0. (Princeton UP, 2009).

$23 \mathrm{R}$ Andersen Jones, 'Litigation, legislation and democracy in a postnewspaper America' (2011) 68 Wash \& Lee L Rev 557.

24 There are needless to say some very compelling First Amendment examples of institutional press defences of free speech including The Pentagon Papers case (New York Times v US (1971) 403 US 713; Nebraska Press Association v Stuart (1976) 427 US 539; and Richmond Newspapers v Virginia (1980) 448 US 555).

25 (1979) 2 EHRR 245.

26 (1991) 14 EHRR 153.

27 [2010] UKSC 1.

28 E Baker, Media, Markets and Democracy (CUP, Mass, 2002), p. 125.
} 
At this point however, different attributes of democratic governing processes are emphasised with the consequence that a different set of optimal structures for the exercise of media freedom are favoured. As the previous section of materials indicated, in seeking a theoretically informed account of the phenomenon of citizen journalism, republican arguments for a virtuous citizenry, participating in non-dominating and deliberative structures of public decision-making are of especial interest to the present inquiry.

\section{Liberal Pluralist Theories}

Liberal pluralist theory starts from the premise that individuals and groups form preferences outside the realm of politics and political structures and that these preferences reflect diverse and conflicting ideas about the nature of the good society. Liberals maintain that the state is not entitled to advocate any particular version of the good life, nor force individuals and groups to deliberate in public with others and defend their exogenously formed preferences. Any reflection (and revision) of preferences and versions of the good life must occur without state interference. $^{29}$ The state's role is limited to ensuring that individuals remain free to assess for themselves the worth of rival conceptions. Within political institutions, liberal pluralists acknowledge that individuals will seek to combine with others in order to influence policy/ legislative outcomes and secure 'fair' bargains in competition with other groups. The laws and policies that emerge in a liberal pluralist state are 'deals' - the product of the relative bargaining strengths of the rival groupings in the arena of politics. This implies a form of political representation in which representatives in the main transmit majority preferences, rather than deliberate and reflect upon these with other representatives. ${ }^{30}$ The fact that some groups are sufficiently influential to shape and limit the sorts of issues that are considered worthy of political resolution is not problematic for the pluralist. From this, it follows that the liberal pluralist conceives of media freedom as a means of (i) ensuring that individuals and groups have access to official information

29 W Kymlicka, 'Liberal individualism and liberal neutrality' in S Avineri and A de Shalit (eds), Communitarianism and Individualism (OUP, Oxford, 1992).

30 C Sunstein, 'Beyond the republican revival' (1988) 97 Yale L J 1539, 1543. This is essentially the position that Gutmann and Thompson in Democracy and Disagreement (Belknap Press, 1998) label 'proceduralist' and which they criticise as unconcerned with longer term, general benefits to the polity as a whole. 
about matters that pertain to their interests and (ii) allowing persons to organise themselves and mount campaigns to advance their interests. These campaigning groups must be free to advocate their preferred policy outcome to lawmakers via media outlets. Liberal pluralist theory thus seeks a range of separate media entities that adequately reflects the range of diverse viewpoints held in the polity and each making the case for a particular outcome/set of outcomes. Media organisations and outlets, on this view, will be highly partisan and promote the diverse viewpoints held by competing groups/individuals.

\section{Republican Democracy}

Liberal pluralism is faulted by republican critics for what the latter claim is an unconvincing account of persons' basic characteristics. The theory's emphasis upon the individual's narrow pursuit of private interests (and association with others to pursue the same), formed exogenously and unchanged by interaction with others in the public sphere is said to fail to capture the complex essence of human nature. Republican accounts of democracy point contrastedly to the unselfish and cooperative aspects of human nature, contending that people are often motivated in some of their actions to some extent at least by notions of the common good. These accounts dispute liberal pluralism's suggestion that persons enter the public realm of politics with fully formed private interests seeking only fair bargains to advance those interests. Instead, it is argued that engagement in the political sphere is valuable leading as it does to self-reflection and, importantly, public deliberation upon matters beyond the purely private and into more general questions of public interest and common good. The deliberative feature of republican democracy is both of instrumental value to the polity (in identifying reasoned outcomes that enjoy support across different groups and individuals and advance the common good) and intrinsically valuable for the individual (in developing understanding of others' perspectives, empathy and other virtues as well as instilling greater attachment to the community). Pluralist decision-making is unconcerned with the benefits that flow from participation in public deliberation and, since pluralist policy outcomes are unsupported by open deliberation and public reason, is considered by republicans to be more likely to yield bad decisions. ${ }^{31}$ Republicans' hope of qualitatively better decisions via open public discourse among citizens as political equals requires there to be a certain level of education among

31 Ibid., p. 1545. 
the participants and means of inculcating the virtues needed for deliberation. Republicanism thus attaches considerable importance to the cultivation and sustainment of virtue among citizens and public officials who, uncorrupted by private interests, can identify and implement policies to advance the common good.

Prior to the renewed interest in 'republican moments' and republican thinking more generally, the central premises of classical republican thought were considered to have little or no application to modern mass democracies and their citizens. Within liberalism for example, sceptical attitudes about the contemporary relevance of Aristotelian thinking are founded upon doubts concerning the validity of its assumptions regarding (i) the notion of a single, common good realisable through virtuous and empathetic discussion among citizens; (ii) the fixed nature of human beings which means that we can only achieve true fulfilment through active engagement in the political life of our communities; and (iii) the practicality in modern mass democracies of seeking to re-create the era of direct 'citizen' rule that briefly existed in early Greek city states.

Against this sceptical background, the revival in modern republican thought stems at the outset from a dissatisfaction with liberalism's emphasis upon state neutrality among competing visions of the good life. At its core, the atomised individual rights-bearer at liberty to choose how best to find personal fulfilment and thus free to decide (inter alia) whether or not to enter the sphere of public discourse appears to sanction apathy and disengagement from the political life of the community. In constitutional terms, Bills of Rights enshrining liberalism's promise of a zone of personal freedoms protected from arbitrary state interference have the potential to deepen this existing apathy by transferring contested issues of moral principle out of political arenas into the courtroom. For republicans, the wholesale judicialisation of rights questions threatens the virtuous political life of citizens and their participation in fora where deliberative reasoning occurs since, 'citizens deprived of the opportunity and the responsibility to grapple with the most significant moral questions lose a vital part of the training in responsibility and self-control that citizenship should bring' ${ }^{32}$

This is not to say that all republicans rule out judicial interventions with majoritarian policy choices under any circumstances. For example, Gutmann and Thompson concede that, upon the production of compelling empirical evidence showing that judicial review best protects the

32 S Macedo, 'Introduction' in S Macedo (ed.), Deliberative Politics: Essays on Democracy and Disagreement (OUP, New York, 1999), p. 3. 
types of rights necessitated by the principle of basic liberty (including freedom of expression), some form of judicial oversight of deliberative decision-making might be acceptable. In their case however, this is a grudging concession. Even where the evidence in favour of judicial resolution was present, the proposal to transfer powers to the courts would still have to be justified to citizens. ${ }^{33}$ The terms of this concession are somewhat paradoxical. Assuming idealised deliberative conditions, Gutmann and Thompson are suggesting that the people in a non-coercive, mutually respectful deliberative forum will be able to agree that they are less suited to the task of defending core freedoms than the courts. ${ }^{34}$ It is difficult to see however precisely how under idealised conditions the need for judicial intervention would arise. Surely, the people as civically virtuous, empathetic and honourable rule-makers would not be expected to trample upon the basic liberties of vulnerable minorities. Obversely, outside idealised deliberative conditions where majorities may, by definition, act in oppressive ways towards minorities, it is not clear exactly how people's agreement to judicial supervision would be forthcoming.

In the republican conception of an inclusive, deliberative democracy, everyone can participate in the formulation of collective ideals and public goals. Crucially, there is a reciprocity at the core of republican deliberative democracy. Citizens are expected to be both reason givers and reason demanders in terms that are accessible to all. As Gutmann and Thompson put it, citizens 'must reason beyond their narrow self-interest' and seek to explain their policy preferences in terms that will make sense to those that disagree with them. ${ }^{35}$ Democracy on this view is an open process in which the public good is defined and advanced through deliberative structures. ${ }^{36}$ So stated, advocates of deliberative democracy believe that the right sorts of decision-making structures will promote the legitimacy of community decisions-making outcomes more acceptable to the 'losers'. With appropriate support from the state to inculcate the necessary element of respect and reciprocity (via educational institutions and other agencies), it is also envisioned that properly designed decision-making

33 A Gutmann and D Thompson, 'Democratic disagreement' in Macedo, ibid. at pp. $247-8$.

34 Although presumably the people would retain the power to resume complete control over decisions affecting the basic liberties.

35 Democracy and Disagreement (Bellknap Press, Mass., 1996), p. 2. There is also an internally reflective dimension to the truly deliberative citizen, see $\mathrm{R}$ Goodin, 'Democratic deliberation within' in J Fiskin and P Laslett (eds), Debating Deliberative Democracy (Blackwell, Oxford, 2003).

36 E Baker, Media, Markets and Democracy (CUP, Mass., 2002), p. 125. 
structures will engender a public-spiritedness in citizens that will carry over beyond formal decision-making structures, making each of us more community-minded and empathetic in other aspects of our interactions with our fellow citizens.

Most controversially, proponents of deliberative democracy tend also to believe that normatively defensible procedures for decision-making will also produce normatively defensible outcomes. Gutmann and Thompson for example endorse the idea of substantively correct principles (such as individual liberty) that lead to substantively correct answers to certain contested moral questions such as abortion and racial discrimination. This has radical implications for free speech doctrine and, implicitly, the freedom of citizen journalists to espouse 'incorrect' viewpoints in online discussion fora. This is a matter which is addressed in further detail below.

Republicanism has played a significant role in western constitutional thinking. The US founding fathers' interest in Greek and especially Roman accounts of the virtues and self-sacrifices needed to sustain republican constitutions was explicitly acknowledged at the time. Jefferson, Adams and Hamilton had all read authors such as Livy, Cicero and Sallust on the rise and fall of the Roman republic and, as Enlightenment thinkers, sought an understanding of the Roman era that would help ensure the longevity of their own republic. ${ }^{37}$ Although some of the framers were doubtful about the ability of persons entering politics to act for motives other than those of self-interest, ${ }^{38}$ there is a rival strand of thought which is more optimistic on this point believing that a certain class of men (leisured, land-owning gentry whose income derived from their status as landowners) would be capable of disinterested public service. ${ }^{39}$ Hamilton for example claimed that the first aim of every political system is to 'obtain for rulers men who possess most wisdom to

37 See further the account in G Wood, The Idea of America-Reflections on the Birth of the United States (Penguin, London, 2011) at ch.2.

38 See for example John Adams, 'A defence of the constitutions of the United States of America' in G Carey (ed.), The Political Writings of John Adams (Regnery Publishing, Washington DC, 2000), where he is scathing of Montesquieu's 'renouncement of self' in these terms 'If absence of avarice is necessary to republican virtue, can you find me any age or country in which republican virtue has existed?' at p. 295.

39 Sunstein, n 30 , p. 1540, has written that it is "no longer possible ... to treat the framers as modern pluralists believing that self-interest is the inevitable motivating force behind political behavior'. 
discern, and most virtue to pursue the common good of society'. ${ }^{40}$ Jefferson maintained that members of this patrician elite (or 'natural aristocracy' as he called them) would endure diminished personal finances in exchange for honourable public service. ${ }^{41}$ Merchants, in contrast, could not be trusted to act disinterestedly for the good of the republic since they would always be inclined to confuse the public interest with their private entrepreneurial activities.

Republican theory has enjoyed renewed prominence in academic circles. In the last two decades, the revival in republican scholarship can be traced to dissatisfaction with liberalism's insistence upon state neutrality. This aspect of liberal theory, republicans argue, has impoverished public life (and the lives of its citizens) by refusing to endorse and inculcate values that are vital to the proper functioning of democratic states. ${ }^{42}$ The 'thin' conception of constitutional freedoms in liberalism which rests upon what Sandel has called 'procedural' notions such as autonomy, choice and rights stands in contrast with 'thicker' or substantive notions endorsed in republican theory. This 'thicker' conception articulates what attributes are needed by virtuous citizens in a modern, well-functioning and deliberative democracy.

Within contemporary republicanism, two broad positions can be distinguished which draw on Aristotelian or neo-Athenian approaches to the ideal polity on the one hand and Roman models of republican thought on the other. ${ }^{43}$ The Aristotelian version of republicanism regards people as essentially political beings whose lives are fully realised when they participate in public life by engagement in deliberative and decisionmaking structures. It holds that self-governing republics must, if they are to endure, cultivate qualities of civic virtue and citizenship that enable citizens to play their part in public life. The state must actively promote these qualities thereby enabling individuals to flourish and develop the attributes necessary for a rich and fulfilling life through which selfmastery may ultimately be achieved. In Sandel's work for example

40 See Federalist Paper No. 63.

41 See Jefferson's endorsement of the 'Roman principle' that public office should be a burden to those that occupy them, bringing 'intense labor and great private loss' cited in Wood, n 37, at p. 71, and see further J G A Pocock, The Machiavellian Moment - Florentine Political Thought and the Atlantic Republican Tradition (Princeton University Press, New Jersey, 1975), p. 515.

42 See in this vein, M Sandel, Democracy and its Discontents - America in Search of a Public Philosophy (Belknap, Mass., 1996).

43 A valuable overview is to be found in J Maynor, Republicanism in the Modern World (Polity Press, Cambridge, 2003) at ch.1. 
constitutions should be read in ways that go beyond the protection of individual autonomy/privacy or the toleration of diversity to endorse substantive moral goods. He is critical for example of decisions such as Planned Parenthood v Casey ${ }^{44}$ where the US Supreme Court reaffirmed Roe $v$ Wade in terms which emphasised the decisional autonomy of the pregnant woman prior to foetal viability. For Sandel, this line of reasoning fails to engage with debates around the substantive moral goods which laws regulating the practice of abortion implicate. ${ }^{45}$

Neo-Roman versions of republicanism differ from their Athenian counterparts in several key regards. At the outset, the linkage in the Athenian model between direct participation in democratic rule-making and personal flourishing and achieving self-mastery is absent in the version of the neo-Roman account associated with Philip Pettit and Quentin Skinner. On this reading of Roman republicanism, greater emphasis is put on the creation and maintenance of constitutional mechanisms that protect individual freedom from tyranny and the misrule of factions by 'tracking' the interests of citizens. ${ }^{46}$ Tyrants and dominant factions alike pose risks of arbitrary interference in the lives of ordinary citizens when they have the power to affect those lives without having to consider what course of action the interests of the interfered agent requires. Absent however are universalist notions of human excellence and flourishing. Machiavelli for instance recognised that individuals held different value systems, were motivated to act for different purposes and pursued different goods. ${ }^{47}$ Thus stated, the neo-Roman model leaves the

44505 US 833 (1992) - state held unable to impose an 'undue burden' on the pregnant woman at the pre-viability stage of pregnancy.

45 Sandel, n 42, p. 98.

46 P Pettit, Republicanism: A Theory of Freedom and Government (OUP, Oxford, 1997), p. 55.

47 Anyone who might see our letters, ... and see their variety, would be greatly astonished, because at first it would seem that we were serious men completely directed toward weighty matters and that no thought could cascade through our heads that did not have within it probity and magnitude. But later, turning the page, it would seem to the reader that we - still the very same selves - were petty, fickle, lascivious, and were directed towards chimerical matters. If to some this behaviour seems contemptible, to me it seems laudable because we are imitating nature, which is changeable; whoever imitate nature cannot be faulted.

Lettere in Opere di Niccolò Machiavelli Vol III (ed F Gaeta) (UTET, Turin, 1984) and cited in M Viroli, Machiavelli - Founders of Modern Political and Social Thought) (OUP, Oxford, 1998), pp. 33-5. 
issue of self-realisation and self-mastery more open-ended. ${ }^{48}$ One of Machiavelli's most controversial and original arguments was his claim that the existence of conflicts between social classes and among individuals/groups belonging to the same class is not only a fact of life but also beneficial. Drawing upon Livy's account of ancient Rome, Machiavelli contends that, properly managed within institutional constraints that involve power-sharing and adherence to the rule of law, social friction among opposing forces of wealthy patrician landowners (grandi) and plebians (popolo) is to be welcomed as creating a dynamic equilibrium which preserves liberty. ${ }^{49}$ As will be seen below, this negative reading of liberty as freedom from arbitrary interference emphasised in Skinner and Pettit is challenged by other scholars such as McCormick who regard it as missing elements in Machiavelli that affirm a more positive, participatory role for ordinary citizens in the policymaking processes of the state.

\section{REPUBLICAN LIBERTY IN NEO-ROMAN ACCOUNTS}

As indicated above, the neo-Roman account of liberty highlights the importance of institutional protections for individual freedom. Freedom is understood in this account to be the absence of external or internal constraint that might be experienced as servitude or personal dependence upon the will of another. For example, the rule of a tyrant or the dominance of the grandi in law-making structures would threaten individual freedom since the pursuit of the narrow self-interests of the tyrant/wealthy landowners would inevitably clash with the common good. Where citizens live in a state of dependency and are at the mercy of others, they cannot be said to be free to pursue the different goals that matter to them. So stated the republican polity aims at safeguarding the liberty of all its citizens. In Machiavelli's work, this aim is achieved by requiring ordinary citizens to play their part in political life, a political life that is also bounded by institutions and laws that applied with equal force to all regardless of rank or status. For Machiavelli, the grandi

\footnotetext{
48 Maynor, n 43, p. 13.

49 Discourses on Livy (Oxford World Classics, Oxford, 1997) Book I, chs 3-6 and see Viroli, n 47, pp. 126-31. The extent to which Machiavelli's republican thought draws upon and develops existing fourteenth century Florentine humanist accounts on liberty is discussed by Quentin Skinner in The Foundations of Modern Political Thought Vol 1 (CUP, Cambridge, 1978) at ch.4.
} 
would never be content with their existing status and largesse. ${ }^{50}$ Driven by the prospect of holding even greater power and being held in even greater esteem, the grandi will seek to advance their private interests (including against fellow grandi) without regard to the common good with a view to establishing dominance over others. The popolo for their part seek much more modest ends, namely to be secure in their lives and homes. They seek only to be free from domination by others. ${ }^{51}$ For this reason, Machiavelli argued, the common people made the best guardians of liberty. It became vital then that the popolo were brought into decision-making assemblies and accorded political equality with the grandi so that some public offices were made open to popolo and grandi alike. The powers of the Roman tribunes (who were elected by the popolo from among their own) included a veto over policies proposed by the grandi in the Senate and the indictment and prosecution of prominent citizens (such as the consuls who enacted the policies of the Senate) suspected of political crimes. The tribunes also proposed laws which were the subject of debate in the plebian assembly.

In seeking stable institutional arrangements in which personal freedoms were secure, Machiavelli and his contemporaries were especially interested in how the Venetian Constitution of 1297 had endured during the serenissima to provide such an extended period of stability and freedom. ${ }^{52}$ The consensus explanation for Venetian success stressed the merits of a mixed constitution where checking mechanisms were in place to make sure that one of the ruling powers was unable to rule without support from the other sections of the population. The Doge (Head of State), shared power with the Senate (aristocratic element responsible for foreign and financial affairs) and the Consiglio Grande (popular element responsible for appointing persons to public office). ${ }^{53}$ Thus, Paruta, a native Venetian writing in the latter half of the sixteenth century, notes in his Political Discourses the absence of domestic conflict, accounting for it on the basis that each aspect of the government is 'limited and corrected' by the other parts of the constitution and that this system

50 'At any rate, in most cases, such disturbances are caused by those who possess something ... men do not believe they truly possess what they own if they do not acquire still more from others.' Discourses on Livy, ibid., ch.5

51 Ibid.

52 Skinner, n 49, pp. 139-41, an inquiry which was particularly acute for Florentines such as Machiavelli whose freedoms had been drastically cut back by the Medicis.

53 See ibid., for an overview of this literature. 
enables the common good to be advanced. ${ }^{54}$ Machiavelli also believed that a mixed constitution which institutionalised power-sharing among classes alongside the provision of meaningful outlets for the expression of disagreement would be more likely to promote outcomes that reflected the common good. ${ }^{55}$ Although in need of constant vigilance, the clashes that ensued when one class proposed the adoption of narrow, selfinterested laws were beneficial to the ultimate preservation of liberty where the institutions existed within which public conflict could be played out and where sufficient levels of civic virtue (understood in the sense later used by Montesquieu as love of the homeland requiring a permanent preference for actions that advance the public good as opposed to private interests) ${ }^{56}$ resided among debating participants. ${ }^{57}$ These robust debates occurred precisely because the ordinary people were involved as civic equals with their land-owning counterparts in the political life of the republic and able to mount resistance to the self-serving proposals of the latter. Popular resistance forced claims originally based on private interests to be revised and reformulated in terms that appealed to and aligned more with the pursuit of the common good. In short, the equilibrium that existed between the senators and the plebs meant that neither could pass laws that oppressed the other. ${ }^{58}$ The laws and institutions that resulted from these instances of discord and tumult were thus also for the 'benefit of civic liberty'.59 Suppose though, Machiavelli says, someone was to object that the means used to maintain liberty were 'almost barbarous'.

I will respond that every city must possess its own methods for allowing the people to express their ambitions, especially those cities that intend to make use of the people in important affairs ... The desires of free peoples are rarely harmful to liberty, because they arise either from oppression or from the suspicion that they will be oppressed. Clearly should these opinions prove to

54 Cited ibid., p. 142.

55 Where by contrast such conflicts lacked outlets for public disagreement (and subsequent compromise) and where the motivations of the agents were exclusively and at all times defined by self-interest then Machiavelli argued, as was the case with Florence, the institutions of that city state would remain unstable and its citizens unfree, see Machiavelli, Discourse on Remodelling the Government of Florence.

56 A Cohler, B Miller and H Stone (eds), The Spirit of the Laws, Book IV, ch. 5 (CUP, Cambridge, 1989).

57 Discourses on Livy, n 49, at ch.4.

58 The tribunes could veto most official acts proposed by the senators.

59 Discourses on Livy, n 49. 
be in error, there is the remedy of public assemblies where some worthy man may arise and ... demonstrate to the people that they are mistaken $\ldots .{ }^{60}$

The recent revival of interest in Machiavelli's republicanism has sparked a lively debate about the precise extent of the role accorded to ordinary citizens in democratic decision-making. One school of thought associated with Quentin Skinner and Philip Pettit conceives the republican ideal of individual liberty set out in Machiavelli in essentially negative terms where a person is not subject to actual arbitrary interference or the threat of arbitrary interference by another (whether the threat emanates from a private person or the state). This account sets out a fairly limited role for ordinary citizens in public life however that is usually limited to participating in elections and considering policy options in narrowly defined circumstances such as referenda. It is sometimes characterised as 'aristocratic republicanism' and is apparent in the ideal of representative government where the people are conceived of as 'indirect' authors of law and policy and who provide through elections a general steer to elected policymakers as to what the popular sense of the common good is. The people are not supposed to play an active and on-going role in deliberation over policy choices.

This view of Machiavelli is said by its critics to underplay a number of elements in The Discourses that value not only the power of ordinary citizens to make socio-economic elites accountable but also which institutionalise a more activist notion of the free citizen within the constitution that goes well beyond voting at elections and referenda. McCormick for example reads Machiavelli as defending ancient Rome's class-specific institutions energised by popular participation and able effectively to police and constrain through active intervention in daily political life the actions of the grandi. ${ }^{61} \mathrm{He}$ points for example to the tribunes' powers of (i) veto over Senate policymaking and (ii) indictment and prosecution of prominent citizens suspected of political crimes. His analysis of The Discourses highlights those elements which accord to the popolo an active role in sometimes raucous deliberative law-making assemblies as well as more indirect forms of power such as voting in elections for public office. McCormick contends that references by republicans such as Cicero, Guicciardini (a younger contemporary of

60 Ibid. Skinner, n 49, notes how Machiavelli's defence of tumults, which was so far removed from Venetian serenissima, appalled his contemporaries, pp. 181-2.

61 J McCormick, Machiavellian Democracy (CUP, New York, 2011) chs 3 $\& 4$. 
Machiavelli) and subsequently Madison to the 'sovereign people' are apt to mask elite domination of political life and the largely passive role of the majority of citizens implicated in these patrician forms of republicanism. Contra Machiavelli, each of these accounts marginalises the position of non-elites to the peripheries of political life. ${ }^{62}$ McCormick argues that by overlooking the sections in Machiavelli that valorise structures facilitating popular participation in law-making and the holding of public officials to account, these accounts fail to have regard to the ability of the wealthy to act in ways detrimental to others. McCormick's reading of Machiavelli is predicated upon passages in The Discourses which set out a favourable assessment of the capacities of ordinary citizens to make sound political judgments in public assemblies after each has had their say in deliberative proceedings. ${ }^{63}$ Machiavelli believes that the same people who say that they want one thing or support one position in their homes or at the tavern in front of their friends often take up different positions when deliberating with others in more formal settings and when the outcome of those deliberations has real consequences for the polity and individuals. In the next section, the alternative perspectives on popular participation in government are explored in more modern constitutional settings.

\section{After Machiavelli - Modernising Republican Theory}

For scholars working within the republican tradition post Machiavelli, the challenge has been to adapt theory to the realities of post-feudal societies well removed from the small-scale city states whose constitutions concerned Machiavelli and his contemporaries. Re-envisioning the 'mixed constitution' and the relationship between institutional structures at national and local levels is an important endeavour in current republican thinking. Part of this debate concerns whether counter-majoritarian institutions such as courts have any role to play in safeguarding liberty

62 Guicciardini maintained that ordinary people should be excluded from proposing and deliberating upon policies. Once the grandi had made a policy decision, the ordinary citizens could then approve/reject it, F Guicciardini, Dialogue on the Government of Florence - Cambridge texts in the history of political thought (CUP, Cambridge, 1994).

63 See thus Book 1, ch. 58 'I declare that a people is more prudent, more stable and judges better than a prince ... As to the judging of things, it is rarely seen that when they hear two speakers who hold opposite views, if they are of equal virtu, they do not take up the better opinion, and they are capable of seeing the truth in what they hear.' and see also Book 1, ch. 18. 
from intrusion by majoritarian bodies. The emergence of representative forms of government in the period after absolute monarchical rule and their continuance under conditions of universal suffrage in contemporary liberal democracies are also notably lacking in what Machiavelli might have recognised as class-specific institutions and offices (or modern day equivalents of plebeian assemblies and the tribunate) to challenge in a formal constitutional setting policy-making by socio-economic elites and which provide fora for active and deliberative engagement by ordinary citizens in daily politics. ${ }^{64}$

\section{(i) Institutional safeguards}

Prior to the industrial era, Madison writing as Publius in The Federalist Papers had already begun to reconceive the republican ideal of the mixed constitution for considerably larger-scale states than had existed in the Roman or Italian Renaissance periods. The federalist proposal of a division of powers between the centre and the states in The Federalist Papers $^{65}$ is one such reconfiguration of the polity. Madison also advocated greater (if still partial) adherence to the separation of powers doctrine (and stronger accompanying checks and balances) than had existed in Great Britain. A particular objective was the creation of greater checks on executive power. ${ }^{66}$ Each branch of the constitution needed to hold some degree of constraining power over the other branches. In this way, the republican constitution would guard against arbitrariness, the 'manipulability of the law ... and ... against government exercising sway over others'. ${ }^{67}$

The rise of a mercantile class who saw politics as a means of advancing their narrow economic self-interests rather than grander and disinterested notions of the public good posed an acute challenge to constitutional architects like Madison. Pocock notes how, 'interest and faction (were) ... the modes in which the decreasingly virtuous people discern(ed) and pursue(d) their activities in politics ...' ${ }^{68}$ Larger-scale political units would, Madison believed, effectively counter the problem

64 Some recent initiatives that have been designed to promote deliberative decision-making among ordinary citizens such as peoples' panels and deliberation days are considered in the final chapter of this book.

65 Federalist Paper No.10.

66 Federalist Paper No.47. See further E Barendt, 'Separation of powers and constitutional government' [1995] PL 599 and for a response N Barber, 'Prelude to the separation of the powers' (2001) 60 CLJ 59.

67 Pettit, n 46, p. 178.

68 Pocock, n 41, p. 522. 
of faction since there would by necessity be a greater number of different parties and interests who were less likely to have a common motive to combine and act contrary to the interest of others. ${ }^{69}$ Accordingly, the preference of the US Founders for diffused power structures at national, state and local levels signifies a response to the problem of dominant majorities in particular localities. ${ }^{70}$ Madison's Federalist Paper No.10 gives expression to his hope that an enlightened and educated elite would emerge triumphant from electoral contests for national public office, an elite that could be trusted to turn away from narrow, parochial interests and dedicate themselves to the discernment and advancement of the national interest. By the late eighteenth century, the idea of class-specific offices and assemblies of the sort favoured by Machiavelli that ensured active engagement by non-elites in law-making and daily political life had been discarded. The sovereign, indivisible 'people' now enjoyed formal juridical equality. There was accordingly no need for non-elites to be accorded their exclusive assemblies and offices. ${ }^{71}$

The prevention of arbitrary interference in the lives of citizens whether caused by the actions of other individuals or the state remains of central importance in republican thought today. The requirement to prevent legislators, judges and administrators acting arbitrarily is considered by Pettit to entail three conditions of constitutionalism which endorse and elaborate upon established liberal precepts such as the rule of law and separation of powers. ${ }^{72}$ Thus in his 'empire of law' condition, Pettit states that laws in a republican polity will be general and apply to all including legislators and executive, published in advance in clear unambiguous terms. Ministers and officials will be required to show legal authority for their actions. Due process will have to be followed. Obscurely/badly constructed laws will fail the 'empire of law' test on the basis that they permit the arbitrary exercise of power by judges or the executive.

Pettit's second condition of republican constitutionalism is the 'dispersal of power' condition. Where the law-making, adjudicating and executing functions are not kept separate, there is a very real prospect of arbitrary interference in the lives of others. Pettit cites Madison's Federalist Paper No.47, 'The accumulation of all powers, legislative, executive, and judiciary, in the same hands, whether of one, a few, or

69 Federalist Paper No.10.

70 See further C Sunstein, The Partial Constitution (Princeton UP, New Jersey, 1993), pp. 18 et seq.

71 Madison endorsed the 'total exclusion of the people in their collective capacity' from governing bodies in Federalist Paper No.63.

72 Pettit, n 46 at ch.6. 
many, and whether hereditary, self-appointed, or elective, may justly be pronounced the very definition of tyranny.' Pettit contends that the overall goal of preventing arbitrary interference may demand, or at least support, additional institutional design features including bicameral legislatures and a federalist division of central/state/regional powers. The former afford a means of enabling a degree of democratic contestation that single chamber legislatures may lack where the voting system produces an under-representation of minority groups. Federalism for its part offers a further check against the over-concentration of power in one part of the government in the way that devolved systems of government do not.

The focus upon the institutional safeguards against arbitrary interference is complemented by Pettit's third and arguably most contentious condition - the counter-majoritarian condition. Laws which express the overriding principle of non-domination should not be capable of amendment by ordinary majorities. Amending measures should have instead to overcome especially onerous procedural hurdles. For Pettit, the fact that a law enjoys majority popular support does not by itself give the law legitimacy. Majorities on specific issues are readily formed in the passion of the moment. Arbitrary, majoritarian interference in the lives of minorities will thus be a constant threat in populist democracies that requires to be guarded against. ${ }^{73}$ Pettit's republicanism does not rule out a judicial role in the policing of instances of arbitrary, majoritarian interference whether when engaged in its interpretative function of applying fundamental constitutional values expressed in Bills of Rights to specific disputes or, alternatively, via exclusively judicially-declared norms of the type articulated in theories of common law constitutionalism. ${ }^{74}$ Though Pettit concedes that the particular set of countermajoritarian institutions and measures to be found in any one jurisdiction will vary according to local circumstances, he nonetheless maintains that it is 'scarcely conceivable that republicans would not endorse any.' 75

A recent strand of republican thought takes direct issue with Pettit's preference for counter-majoritarian institutions and has fiercely critiqued what it terms 'legal constitutionalism' whereby the courts are accorded a greater role in preserving individual liberty in rights litigation. Tomkins for example makes a 'republican' demand that disagreement over matters

73 See thus Allan's comment that republicanism does not equate to 'majority decision-making according to the passions of the moment', T R S Allan, 'Our Republican Constitution - A Tomkins' (book review) [2006] PL 172, 173.

74 See thus T R S Allan, Law, Liberty and Justice (Clarendon Press, Oxford, 1994).

75 Pettit, n 46, p. 181. 
of fundamental principle be exclusively determined by the legislature ${ }^{76}$ while Bellamy argues the case for a 'political constitution' that upholds a majoritarian conception of rule-making in part because he holds that majority rule-making is able to track minority interests. ${ }^{77}$ McCormick for his part chides Pettit for his fixation upon the deficiencies of popular decision-making, claiming that Pettit's stance:

seems motivated by the largely unfounded belief that decisions by the few are generally correct, that is more often conducive to the common good ... a standpoint that presumes that reason most likely resides among an elite few $\ldots . . .^{78}$

To arrive at a more efficacious and participative version of liberty as non-domination, McCormick claims that Pettit would do well to recast his preferred institutional design to capture and give free rein to popular decision-making structures of the sort praised by Machiavelli. Public assemblies, it will be recalled, function in The Discourses as deliberative fora that can be relied upon to arrive at the truth in policy-making, select better candidates for public office and thus advance the common good. The ordinary people there are capable of making the better decisions in these cases since the weaker arguments/candidates will be found out in public discussion among the many. On this view, the defence of even limited forms of judicial review in large-scale modern democratic states is misplaced since it transfers power impermissibly away from the (elected representatives of the) people and into the hands of an elite group.

It may be however that McCormick overstates Machiavelli's faith in the truth-discerning powers of the public assembly. A close reading of The Discourses reveals Machiavelli to make only the comparative claim that the ordinary citizens gathered in public assemblies and deliberating together are more likely to come to better decisions (decisions in the public good) than the consuls in the elite (grandi) dominated comita centuriata. His position is not that wisdom always lies with a majority of the people or that their judgement is always liberty enhancing. ${ }^{79} \mathrm{He}$

\footnotetext{
76 A Tomkins, Our Republican Constitution (Hart, Oxford, 2003).

77 R Bellamy, 'Republicanism, democracy and constitutionalism' in C Laborde and J Maynor (eds), Republicanism and Political Theory (Blackwell, Oxford, 2008).

78 J McCormick, Machiavellian Democracy (CUP, New York, 2011), pp. 164-5.

79 Discourses Book 1 ch.53 noting how the people formed an unfavourable assessment of Fabius Maximus when he proposed a cautious strategy to deal
} 
acknowledges that ordinary citizens are prone to being misled by elements among the grandi who manipulate public opinion for their own ends. He also maintains that sometimes the grandi will identify correctly what is in the best interests of the whole community. ${ }^{80}$ It seems clear then from the foregoing that Machiavelli did not discount altogether a checking role for non-majoritarian institutions outside the public assembly. It follows that he cannot be read today as implacably opposed to any role for judicial agencies in maintaining liberty.

Fast forward five hundred years from the city states that Machiavelli knew to modern systems of representative democracy and it is seen that ordinary citizens experience indirect, intermittent and generalised accountability of office holders only. Elected representatives and governments can themselves become agents of domination when they fail to track citizens' interests. This failure occurs for a variety of (sometimes overlapping) reasons including the failure to keep campaign promises, broad discretionary powers that enable a variety of policies to be executed, the efforts of powerful, well-financed lobby groups enjoying superior access to politicians and the occurrence of unforeseen events demanding an immediate response. A good example of the latter is provided by official responses to terrorist attacks. In reacting to the latest barbarous act of certain Islamic fundamentalists, the counter-terrorism policies of Conservative and Labour Governments often play to a populist agenda of rights-curtailment (freedom of association, freedom of speech and privacy) in the unevidenced hope of promoting greater security for UK citizens. In the autumn of 2014, following the beheadings of UK and US citizens and the involvement of some British Muslims in jihadist groups, the Home Secretary announced - without any apparent sense of irony - to the Conservative Party Conference proposals to bolster British values such as freedom of speech by limiting the speech of those who hold 'un-British' views and to grant the police and security services greater powers to monitor internet and mobile phone usage. ${ }^{81}$ She proposed giving the police the power to seek 'extremism disruption

with Hannibal's forces. The ordinary citizens' preference for the bolder plan of Varro led to defeat at Cannae, the loss of several city states to Carthage and almost precipitated the fall of Rome itself.

80 Ibid., ch.54 recounting the people's mistaken decision to send half the population of Rome to Veii.

81 'Theresa May vows Tory Government would introduce "snooper's charter" The Guardian September 30, 2014 http://www.theguardian.com/politics/ 2014/sep/30/theresa-may-tory-government-snoopers-charter. 
orders' to restrict the 'harmful activities' of individuals, including banning broadcasts and requiring speakers to submit web/social media/print publications to the police in advance. 'Harmful' is defined to include a mere 'risk of public disorder, harassment or alarm or distress'. Taking part in public protests or speaking at an event subject to a ban would be a criminal offence. In the aftermath of the Conservative Party's election victory in May 2015, legislative proposals have been announced (i) to extend state surveillance powers to obtain electronic data; (ii) to confer prior restraining powers on OFCOM with a view to censoring programmes containing 'extremist' views; and (iii) to impose a duty on public bodies such as universities, schools, local authorities, healthcare bodies to have 'due regard to the need to prevent people being drawn into terrorism.'

John Hart Ely made a powerful case for subjecting majoritarian rule-making to non-majoritarian, judicial review in Democracy and Distrust. ${ }^{82} \mathrm{He}$ argued that existing power holders were prone to "choke off' the channels of political change, making it more likely that the 'ins' would remain in power. Representatives 'beholden to an effective majority' might systematically disadvantage minority groups out of 'simple hostility or a prejudiced refusal to recognise commonalities of interest'. ${ }^{83}$ The courts, in his view:

must police inhibitions on expression and other political activity because we cannot trust elected officials to do so; ins have a way of wanting to make sure the outs stay out ... they should not be permitted to inhibit it for some flimsy reason that is in fact being used as a pretext. But even this cannot be enough. Perspective is critical, and one whose continued authority depends on the silencing of other voices may well in all good faith be able to convince himself that a reason a more objective observer would label inadequate is in fact compelling. ${ }^{84}$

While the channels of political change that permit active deliberation by ordinary citizens (including unpopular minorities) may not always have been safeguarded by UK courts, it seems churlish to deny the past record of the courts in this regard or to overlook the institutional capacity of the courts to remain detached from the populist pressures that affect governments and MPs and become particularly strong in the period immediate prior to elections. The House of Lords in ex parte Simms for example

82 J Hart Ely, Democracy and Distrust - A Theory of Judicial Review (Harvard University Press, Mass. 1980).

83 Ibid., p. 103.

84 Ibid., pp. 106-7. 
evidences the commitment of the common law to preserve the freedom of prisoners to campaign against miscarriages of justice. ${ }^{85}$ The context in Simms was a government policy that prohibited oral interviews with journalists unless the journalists signed a written undertaking not to publish any part of the interviews but the ruling rests on the broader common law principle of legality whereby fundamental individual rights (including freedom of expression) are not considered by the courts to be overridden except by express statutory language or by clear and necessary implication. As for protection of freedom of association, the courts/tribunals have also taken an appropriately rigorous look at the Home Secretary's powers to de-proscribe an organisation that had been banned on grounds of it being concerned in terrorist activity. In Lord Alton of Liverpool $v$ Home Secretary, ${ }^{86}$ the latter's failure to consider exercising his powers to de-proscribe the People's Mojahadeen of Iran (PMOI) was deemed 'perverse' in the face of 'incontrovertible' evidence that the PMOI had not been involved in terrorist activity for a number of years. The Home Secretary had erred in law by attaching undue weight to the failure of the PMOI to renounce terrorism in a public statement. At supranational level, the jurisprudence of the European Court of Human Rights on Articles 10 and 11 (freedom of expression and association) has long placed greater importance on the value of political speech in comparison to commercial or artistic speech forms. ${ }^{87}$ This is made manifest in a closer degree of supervision of national authorities' restrictions on political expression and association than is applied to national restrictions on non-political expression. ${ }^{88}$ This satisfies Ely's requirement of subjecting restrictions on political expression to intense

85 Lord Steyn recognised in Simms that 'it is not easy to conceive of a more important function which free speech might fulfil', $R v$ Secretary of State for Home Department, ex parte Simms (1999) at http://www. publications.parliament.uk/pa/ld199899/ldjudgmt/jd990708/obrien01.htm.

86 (2007) Proscribed Organisations Appeal Commission (Judgment November 30) Appeal No: PC/02/2006.

87 See thus Animal Defenders International v UK (2013) 57 EHRR 21, concurring opinion of Sir Nicolas Bratza:

(T)he Court has consistently emphasised the fundamental role of freedom of expression in a democratic society, where it serves to impart information and ideas of general interest, which the public are moreover entitled to receive. It has also emphasised the high level of protection afforded to political speech and has, in general, required an especially pressing social need if restrictions are to be imposed on it' (para.5).

88 See e.g., Castells v Spain (1992) 14 EHRR 445 and contrast with the wider margin of appreciation afforded to national authorities when regulating 
scrutiny in order to prevent self-serving 'ins' from closing off the channels of political change.

The respective positions of Bellamy and Tomkins favouring exclusively majoritarian rule-making institutions as means of tracking minority interests and determining rights questions were noted above. Much rule-making by the UK's executive-dominated Parliament in recent times on matters concerned with terrorist suspects, welfare claimants, migrant workers and dissenting/unpopular forms of expression points in the opposite direction however, tending to provide regular empirical refutation of Bellamy's remarkable claim that electoral majorities do protect minority interests. ${ }^{89}$ Tomkins' argument for its part rests upon an erroneous claim that a contestatory democracy can flourish within the confines of an exclusively majoritarian system of parliamentary rulemaking. Specifically, his disregard for the role played by UK common law via the principle of legality in safeguarding (albeit to a limited extent) individual freedom from populist interference serves in particular to undercut his overall argument. 90

\section{(ii) Civility, community and outrage: Some freedom of expression concerns raised by current republican thinking}

A reader with only a passing sense of the essentials of constitutional arrangements in the UK will readily appreciate that the idealised positions staked out by Pettit to secure liberty as non-domination display at best a limited match with constitutional reality. Thus, while the 'empire of law' condition is plainly satisfied, the 'dispersal of power' and 'democratic contestation' requirements are at best only weakly exemplified. It is true that the Constitutional Reform Act 2005 has provided greater institutional separation between the legislature and judiciary. Nonetheless, executive dominance of the legislature remains and asymmetric patterns of devolution do not equate to federalism, although this is clearly a fluid area of the constitution after the Scottish referendum vote and the General Election result of May 2015. Neither is it the case that the partly-hereditary, mainly-appointed House of Lords facilitates 'democratic' contestation of the House of Commons' rule-making in the way

speech on unfair competition grounds in Markt Intern Verlag Gmbh v Germany (1990) 12 EHRR 161.

89 Bellamy, n 77. His subsequent concession on p. 183 that there may be some groups possessing no or negligible political influence that legal constitutionalism can make a difference to leaves the reader wondering just how much of his objection to counter-majoritarian decision-making structures remains intact.

90 Examples include ex parte Simms discussed above. 
that wholly elected Senates in other constitutions do. Finally, the limited nature of counter-majoritarian constraints on executive-dominated lawmaking (such as the principle of legality) leaves minorities vulnerable to populist and arbitrary forms of liberty encroachment by an executivedominated legislature. The many and major pieces of constitutional reform needed to address these 'unrepublican' deficiencies are well beyond the scope of the present inquiry. Of central interest in the current chapter is to consider how, viewed through the frame of an admittedly idealised version of republican constitutionalism, legal responses to developments in electronic forms of communication might be assessed. Recall the suggestion by Tran that today's social media platforms offer the possibility for an increased frequency of 'republican moments' and the accompanying claim that, in between such moments, social media hold out the prospect of more deliberative and participatory decisionmaking than occurs under 'politics as usual'. ${ }^{91}$ To examine this claim more fully, the remainder of this introductory chapter examines core features of two distinct accounts of republican thinking that inform the type and extent of constitutional protection for speech. As will be shown below, one account rests upon an objectively-determined version of the common good while the other is predicated upon community-determined norms of civility in public discourse. Each account fails in different ways to protect the autonomy interests of speakers and audience, allowing not only the content of speech to be censored but also excluding from deliberative fora the uncouth, disrespectful and uneducated. The cleansing of public discourse that is thereby achieved poses some acute questions about self-government and participative politics.

To restate the main components of republicanism: politics is essentially a deliberative activity in which individual citizens and groups (holding and seeking to advance private interests) participate as equals with others in open forums designed to produce outcomes that advance common interests and the public good. Meaningful deliberation which entails reflection, dialogue and a willingness to revise existing positions is dependent upon the attribute of civic virtue (including the capacity for empathy with others) and a certain background level of educational attainment. Indeed, for Michelman deliberation in the community means

91 Tran, n 19. 
that the citizens leave behind their private interests and share in 'reconciliatory projects' that yield up the consensual common good.92 Participation in political life is critical for informed self-government and the attainment and maintenance of liberty. ${ }^{93}$ Thus stated, it can be inferred that freedom of speech and freedom of information are required to be adequately protected for republican-style deliberation to occur.

Cass Sunstein's account of modern republicanism's central commitments identifies four, interlinked principles - deliberation, political equality, universalism and citizenship. ${ }^{94}$ Underpinning each is the foundation value of 'civic virtue', a simultaneously procedural and substantive concept that requires citizens to advance the public good both in terms of the outcomes of deliberative processes as well as during the deliberative process itself by respectful, non-dominating empathetic conduct towards others and the institutions set up to maintain liberty. ${ }^{95}$ The notion of political equality requires all citizens to have access to the deliberative sphere. Large ranges of wealth are troublesome because of their tendency to produce disparate levels of influence on political debate. It follows that, where wealth differences produce disparate levels of political influence, some corrective, equalising measures may be called for. ${ }^{96}$ Although Sunstein is silent on the point, the problem of unequal wealth in republican thinking is exacerbated by the absence of modern

92 F Michelman, 'The Supreme Court 1985 term-Foreword: Traces of self-government' (1986) 100 Harv L Rev 4, 33.

93 On neo-Aristotelian accounts, regardless of the wider consequences it produces, participation in the political life should be seen as intrinsically valuable.

94 Sunstein, n 30. See also R Dagger, Civic Virtues - Rights, Citizenship and Liberal Republicanism (OUP, Oxford, 1997) who at p. 14 and borrowing from Burtt (and Montesquieu) defines 'civic virtue' as 'simply the disposition to further the public good over the private good in action and deliberation'. Dagger argues that 'civic virtue' survives in the modern polity in 'various forms' including the call upon citizens to do their civic duty by turning up to the polling station on election day. In Machiavelli's day, civic virtue also connoted patriotic courage of the sort needed to repel the external enemies of the republic.

95 This is more constraining certainly in terms of the style of discourse than that described by Machiavelli in Book IV of The Discourses where he refers positively to the 'disturbances' between the plebeians and the nobles and links this discord to the creation of (i) good laws and (ii) the office of the tribunes both of which secured the liberty of the people. Sunstein appears somewhat unrealistically to want something that is closer to respectful, academic-seminar modes of discussion.

96 See for example debates around the financing of political parties' electoral campaigns. 
equivalents of the plebeian assembly and the tribunate - fora that are class-specific that enable non-elites to challenge and call to account/veto the actions of their socio-economic superiors.

In respect of 'universalism' Sunstein, like Michelman, believes in 'mediating' via dialogue and deliberation different conceptions of the public good to arrive at 'substantively correct outcomes, understood as such through the ultimate criterion of agreement among political equals'. 97 There is a discoverable 'common good' to be attained at the end of a 'well-functioning deliberative process'. ${ }^{98}$ Discussion will make plain that some values are superior to others, that some values are 'good' values and others are 'bad' values. Sunstein believes that the outcomes of deliberative processes can be externally assessed by reference to some objective value structure that comprises the 'common good'. The issue of how well the deliberative processes are functioning can thus be determined by comparing the decisions reached at the conclusion of the deliberations with this external value structure and the substantively right answers it should have yielded. ${ }^{99}$ Nonetheless, Sunstein is careful to qualify his principle of universalism by entering the caveat that republicans reject both the idea in all cases of a unitary public good and consensus through dialogue. Republicans accept, he argues, that:

differently situated individuals and groups will frequently be unable to resolve their disagreements through conversation ... The republican position is not that every issue is subject to political resolution; it is instead that some questions can yield general agreement through deliberation. ${ }^{100}$

Naturally, this concession leaves several unanswered questions. On which issues will agreement not be possible? In such cases, is there not a danger of unchecked majoritarian rule-making that fails to track minority interests?

Internet communications on social media platforms appear to facilitate unparallelled opportunities for republican-style, citizen-centred dialogue on the topics of the day, drawing upon and responding to published government data that is accessible on a scale that has never been

97 Sunstein, n 30, p. 1554.

98 Ibid.

99 M Redish and G Lippman, 'Freedom of expression and the civic republican revival in constitutional theory: The ominous implications' (1991) 79 Cal L Rev. 267, 269-70.

100 Sunstein, n 30, p. 1555. There are some issues which ought to be kept outside of the political arena altogether. Sunstein gives the example of issues to do with religion without clarification or further explanation. 
experienced before. Released from the sheer physical constraints of geographical dispersion, Twitter, Facebook and Youtube allow for content production, sharing, opinion, debate by citizens and those holding public office alike. The Obama administration has for example been pro-active in urging federal agencies not only to go online with details of their activities and decision-making so as to make the work of government transparent but also to solicit public feedback so that government is able to be responsive to the concerns of the electors. Participation by non-elites in social media is said to exemplify the ability of the internet to promote deliberation among political equals. Although there are still age and income barriers to participation, it is not misleading to say that social media sites have contributed to a democratisation of speech in which a large number of citizens no longer participate solely in their capacities as members of the audience while elites monopolise policy debates but are engaged as speakers interacting with the speech of elite public office holders and prominent media commentators. The ease with which internet users can conceal their true identities is useful here in reducing the scope for irrelevant fellow user response based on a perception of the speaker's race, gender, etc., - although it prompts other concerns about the facilitation of abusive and hateful forms of expression. The sheer range and diversity of speakers and viewpoints produces its own set of problems however, chief among which is audience fragmentation - the ability of the speaker to command an audience. Many of us may be newly empowered speakers, but who is listening to us? What impact on political debate are we able to have? This is a matter which has major implications for republican theory and is returned to in Chapter 2. For the time being, I want to return to the 'universalism' aspect of Sunstein' republican theory as it applies to freedom of expression and ask how much leeway is given to dissenting opinion and individual autonomy among the civically virtuous citizens.

The republican ideal is a deliberative community in which all citizens come together to resolve their differences and agree on the public good. As we have seen above, Sunstein's universalism posits the existence of an external, objectively-determined right answer (on some occasions at least) to the questions that come before the citizens for deliberation. As critics have previously pointed out, this is problematic for a number of reasons: First, it seems to pre-empt the deliberative process. If there is a 'right' outcome that may be determined by the application of an external value system, what's the point of deliberating other than to sharpen one's 
rhetorical powers? ${ }^{101}$ In itself, the premise of objectively-determined moral truths severely curtails individual freedom. Given the existence of 'right' and 'wrong' answers, might not the elected majority be entitled/ obliged to direct citizens away from the 'wrong' answers, penalising those who persist in the misguided advocacy of erroneous viewpoints with the coercive powers available to majoritarian-controlled institutions. Consider however the alternative scenario in which the majority are for some reason not properly attuned to the 'common good'. Here the majority will at some point use their legislative powers misguidedly to prohibit viewpoints that, as Sunstein's value system would have it, are in truth 'correct'. In these circumstances, the majority's error will need to be corrected by counter-majoritarian means. Sunstein seems thus committed to both popular restriction of minority and unpopular viewpoint expression as well as to counter-majoritarian restraints (such as judicial review) on the majority's ability to restrict speech. In determining in any given case whether to uphold or strike down majority restrictions, the critical factor will be the viewpoint that is suppressed. Either way, government neutrality is abandoned as state institutions take sides in the contest between rival ideas. Here Sunstein looks to have assumed a degree of infallibility of the sort that the moral scepticism of Oliver Wendell Holmes famously satirised in Abrams $v$ US. ${ }^{102}$ Once the existence of objective truths is granted, it could be said alongside Holmes that viewpoint-based regulation makes complete sense in order to close off wasteful and diversionary discussion of 'wrong answers' contributed by opponents of the 'common good'.

On this reading, Sunstein's republicanism appears hostile to dissenting voices and thus to claims of individual autonomy and rights that underpin the freedom to dissent. His republican state would seem then to have little problem in principle with the criminalisation of 'wrong' answers. ${ }^{103}$ Moreover, if the dissenters are to participate meaningfully in future deliberations, they may require educating in the ways of 'virtuous'

101 Redish and Lippman, n 99, p. 287, describe such deliberation as a 'sham'.

102 See his dissent in Abrams v US (1919) 250 US 616. 'Persecution for the expression of opinions seems to me perfectly logical. If you have no doubt of your premises or your power, and want a certain result with all your heart you naturally express your wishes in law, and sweep away all opposition.' For valuable insights into the background to Holmes' opinion see T Healey, The Great Dissent - How Oliver Wendell Holmes Changed His Mind and Changed the History of Free Speech in America (Metropolitan Books, New York, 2013).

103 S Gey, 'The unfortunate revival of civic republicanism' (1993) $141 \mathrm{UPa}$ L Rev 801, 861-5. 
conduct, especially where the losers' debating style and content is overly robust and lacking in empathy. ${ }^{104}$ To be fair to Sunstein, he does acknowledge the danger that republican governments might 'overreach' themselves in the pursuit of a civically virtuous society. ${ }^{105}$

If it is conceded that deliberation Sunstein-style in unitary public/ common good cases is under-protective of individual autonomy and dissenting viewpoints, it can be asked whether other 'republican' accounts of the deliberative pursuit of the 'common good' are less censorious of minority opinion and commensurately more receptive to autonomy and dissent. A more promising account (initially at least) that appears to offer hope in this regard is Post's account of democracy as active and mediated self-rule by the citizens. That is to say, for citizens to experience government as their own government, each person 'must have the warranted conviction that they are engaged in the process of governing themselves'. ${ }^{106} \mathrm{~A}$ vital aspect of this 'warranted conviction' is the belief that the state is responsive to the values of each of us and that each person has the opportunity to influence public debate through advancing ideas and arguments. Provided that the 'warranted conviction' condition holds true, then the citizens in Post's deliberative democracy will be able to identify and maintain their identification with the state and its decision-making processes even if the actual outcomes of public discourse fail at times to reflect each citizen's values (as they must). To enable this identification with the state, it is required that each person be treated equally with other citizens in the sense of an autonomous, self-determining citizen. The citizen must be free to decide whether and how to contribute to public debate. If the state regulates too readily the expressive activity of citizens, there will be a loss of autonomy on the part of the censored citizens and a consequent inability to influence

104 The private associational relations held by individuals may constitute one means by which groups of persons enter the public deliberative sphere with previously formed viewpoints and attitudes that hinder an open-minded search for the common good, see S Gey, ibid., p. 816.

105 Contrast nonetheless Sunstein's universalism with Ely's (n.80) qualified defence of judicial review which does at least set out a role for countermajoritarian institutions (including constitutional courts) in correcting majoritarian determinations of the public good where there is a closing off by the majority of avenues of political change. On Ely's terms, the freedom to contest elections and hold existing office holders to account is not confined to those who conduct themselves in a civically virtuous way, treating opponents with respect and empathy.

106 R Post, 'Democracy and equality' (2006) 603(1) Annals of the Am Acad Pol \& Soc Sci 24, 26. 
the outcome of public discourse. Those so excluded will experience a loss of 'democratic legitimacy' and feel alienated from the process of self-government.

As with Sunstein however, Post's position on deliberative democracy also manifests an anti-autonomy, pro-censorship attitude towards certain kinds of speech. It surfaces in his analysis of the Supreme Court ruling in Hustler Magazine $v$ Falwell ${ }^{107}$ in which he endorses the view that the demands of civility in public discourse can legitimately ground the silencing of certain 'outrageous' speakers. ${ }^{108}$ Hustler it will be recalled decided that a public figure was prevented by the First Amendment from obtaining damages for the intentional infliction of emotional distress caused by outrageous and offensive speech unless he/she could show that the defendant speaker had made a false statement of fact with actual malice. Post argues that Hustler reveals a paradox at the heart of the First Amendment's purpose of promoting a highly protected zone of public discourse. A fully functioning system of public discourse requires government neutrality. Those advocating rival viewpoints must be free to persuade citizens from all communities round to their side without being disfavoured/favoured by officialdom. Were the government to prohibit a viewpoint on account of one community's sense of outrage, this would distort the clash of ideas by favouring or disfavouring one of the participants. The paradox arises, Post claims, because the idea of public discourse presumes an acceptance of rational standards of deliberation and the 'civil', non-invasive, non-coercive conduct of speakers and listeners. For speech to be of service in a self-governing democracy then, a deliberative polity must have a means of distinguishing the 'rational' thought from the 'irrational' thought, the 'civil' contribution from the 'uncivil' contribution. This is the function played by community norms in Post's scheme. He contends that speech under the type of republicanism fostered by the First Amendment can be legitimately excluded from public discourse if it is 'considered or experienced as coercive or invasive or otherwise a violation of one's identity or freedom'. ${ }^{109}$ Thus the person who burns the national or regional flag can be justly sanctioned by the criminal law where, as will normally be the case, a majority of

107485 US 46 (1988).

108 R Post, 'The constitutional concept of public discourse: Outrageous opinion, democratic deliberation, and Hustler Magazine v Falwell' (1990) 103 Harv L Rev 601.

109 Ibid., p. 642. 
community members perceive their sense of identity and standards of civility to be under assault and public discourse 'seriously undermined'. ${ }^{110}$

The paramountcy that Post accords to community rules of civility in determining the boundaries of constitutionally protected speech means however that a dominant community or elite group is able to have its value-laden notions of appropriate and inappropriate public speech enforced by legal sanction against others. In these circumstances, government neutrality is utterly abandoned to the sensitivities of powerful factions. Speech that is deemed outrageous to public morals has been particularly vulnerable to majoritarian sentiment as US experience in the 1870s under the Comstock Act reveals. Sponsored by a fervent moral crusader Anthony Comstock whose campaigning soundbites included 'morals, not art or literature', Congress passed the 1873 Act which declared that contraceptives were illicit and immoral, criminalising the mailing between states of contraceptives and advertisements for the same. The Act extended to a wider set of materials that were considered 'lewd, indecent, filthy' including the works of George Bernard Shaw, the plays of Chaucer, Tolstoy and anatomy texts for medical students. ${ }^{111}$ The Act survived First Amendment scrutiny in ex parte Jackson. ${ }^{112}$

As Fallon has cogently argued in response to Post, public discourse can proceed perfectly well independently of any group's notions of outrageous speech. ${ }^{113}$ Conversely, the application of elite-generated norms of civility and decency to determine the outer limits of constitutionally protected speech is likely to have the effect of marginalising expressive forms that advocate unpopular viewpoints, or, regardless of the substantive viewpoint expressed, are stated in crude and disrespectful

110 R Post, 'Community and the First Amendment' (1997) 29 Ariz St L J 473, 483.

111 It is estimated that, as Inspector for the Post Office between 1874 and 1915, some 120 tons of printed materials were seized by the state, http:// www.firstamendmentcenter.org/banned-books. Comstock was later heard to boast that he had secured the criminal convictions of sufficient numbers of men and women to fill a 61-carriage train!

11296 US 727 (1877) and see further for excellent commentary D M Rabban, Free Speech in its Forgotten Years 1870-1920 (CUP, Mass., 1999).

113 R Fallon, 'Post on public discourse under the First Amendment' (1990) 103 Harv L Rev 1738, 1740-41. For Fallon, Rawlsian liberalism requires the state to be neutral between different communities' views of what is good and bad in public life and would not permit one section of the population to have its own morality forced onto others. 
terms. This marginalisation is not consistent with active and informed self-government.

\section{CONCLUSION}

In The Discourses on Livy, Machiavelli's prescriptions for the maintenance of liberty in the republican city-state are not founded upon a previously expounded theory of individual liberty that expressly draws upon notions of autonomy of the person or the legitimate authority of the state. ${ }^{114}$ Free speech scholars today will likewise look in vain for a theorised account of the instrumental role played by non-elite citizens in safeguarding the health of the polity. There is no explicit statement in The Discourses about the value of minority opinion or the 'right' to dissent in the plebeian assembly or tribunate. That said, one of the most original features of The Discourses is Machiavelli's ringing endorsement of a vibrant and disputatious political culture between the elite patrician class and the plebs as a means of preserving liberty and advancing the common good. He describes scenes in Chapter 4 of Book 1 that he was well aware would be interpreted by some as a dysfunctional and chaotic level of discord:

But someone may object, the means used were extraordinary and almost barbaric. Look how people used to clamour and assemble against the senate, and how the senate decried the people, how men ran helter-skelter about the streets, how the shops were closed and how the plebs en masse would troop out of Rome - events which terrify, to say the least, anyone who read about them. ${ }^{115}$

For Machiavelli, these 'tumults' were nonetheless successfully managed within Roman institutions and produced good laws that advanced the common good and public liberty:

I say that those who condemn the tumults between the nobles and the plebs, appear to me to blame those things that were the chief causes for keeping Rome free, and that they paid more attention to the noises and shouts that arose in those tumults than to the good effects they brought forth, and that they did not consider that in every Republic there are two different viewpoints, that of the People and that of the Nobles; and that all the laws that are made in favor of liberty result from their disunion ... I say, that every City

114 J Plamenatz, Machiavelli, Hobbes and Rousseau, M Philp and Z A Pelczynski (eds) (Oxford, OUP, 2012), pp. 44-8.

115 N Machiavelli, The Discourses Book 1 ch.IV. 
ought to have their own means with which its People can give vent to their ambitions, and especially those Cities which in important matters, want to avail themselves of the People .... .116

He also manifests a confidence in public debate in the assembly to expose false opinions:

And if these opinions should be false, there is the remedy of haranguing (public assembly), where some upright man springs up who through oratory shows them that they deceive themselves; and the people (as Tullius Cicero says) although they are ignorant, are capable of (appreciating) the truth, and easily give in when the truth is given to them by a trustworthy man. ${ }^{117}$

Machiavelli's ground-breaking insight into the beneficial consequences of discord and tumultuous speech has been lost to a number of contemporary writers in the republican tradition in their efforts to establish a civilised sphere of public discourse. In Chapter 3 of this monograph, this theme is taken up once again and developed further.

116 Ibid.

117 Ibid. 